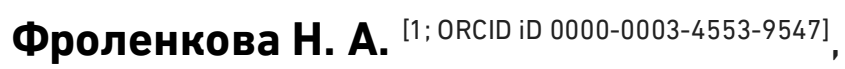
к.е.н., доцент

'Національний університет водного господарства та природокористування, м. Рівне

\title{
УПРАВЛІННЯ ІНФРАСТРУКТУРОЮ ЕЛЕКТРОННОГО РИНКУ
}

У статті визначені основні передумови діяльності сучасних бізнесструктур на електронному ринку. Визначені основні учасники та особливості функціонування елементів інфраструктури електронного ринку. Охарактеризовані різні типи вебсайтів, як елементів ринкової інфраструктури.

Ключові слова: електронний ринок; інфраструктура; учасники ринку; вебсайт.

Постановка проблеми. Сучасний етап розвитку економіки України характеризується низкою тенденцій та проблем, що робить надзвичайно складним процес виживання та розвитку підприємств в усіх галузях. Зростання кількості конкурентів у всіх сферах, перенасиченість ринку товарами і послугами, зміна потреб споживачів змушує бізнес-структури шукати шляхи розширення цільових сегментів, диверсифікації своєї діяльності. Одним з найбільш перспективних сучасних способів диверсифікації є вихід на електронні ринки. Адже з підвищенням доступності Інтернету, розвитком систем автоматизації управління підприємством, споживач отримав доступ до величезної кількості інформації про товари і послуги, можливість вибору кращих з них, а бізнес-одиниці - можливість розширити цільові сегменти, одержати оперативну інформацію про потреби споживачів, знайти оптимальні шляхи постачання.

Взаємодія споживачів і постачальників в Інтернет-середовищі визначає функціонування інтерактивного електронного ринку. Такий ринок надає нові можливості комунікацій 3 постачальниками $\mathrm{i}$ споживачами, більш ефективні технології продажів.

Невирішена раніше частина загальної проблеми. Переваги виходу бізнесу на електронні ринки сумнівів не викликає. Проте сьогодні відсутня систематизована інформація про електронний ринок, його інфраструктуру, особливості функціонування суб'єктів 
ринкових відносин.

Цілі дослідження. Метою дослідження є виявлення основних елементів інфраструктури електронного ринку, оцінка їх переваг і недоліків, особливостей ведення бізнесу.

Основні результати дослідження. Електронний ринок (е-ринок, e-market) в широкому розумінні являє собою систему економічних відносин у віртуальному просторі, які складаються між суб'єктами економічної діяльності стосовно ведення електронного бізнесу, укладання угод, реалізації товарів, послуг та інформації, а також для підтримки комунікацій між продавцями і покупцями, що характеризуються певними закономірностями в умовах розвинутої структури інформаційних комунікаційних технологій та систем.

Розрізняють горизонтальний ринковий простір для надання товарів і послуг масового попиту і вертикальний ринковий простір, що віддзеркалює специфіку окремих галузей економіки.

Електронний ринок являє собою середовище 3 більш досконалою конкуренцією ніж традиційний ринок. На електронному ринку значно більша кількість продавців і покупців, практично відсутні бар'єри для виходу на ринок нових учасників, є вільний доступ до інформації. Переваги ведення господарської діяльності на електронному ринку:

- наявність якісної і доступної інформації для проведення маркетингових досліджень;

- інтерактивність і сумісність дій в реальному масштабі часу;

- висока оперативність взаємодії з клієнтами, постачальниками, партнерами;

- можливість роботи одночасно з великою кількістю клієнтів; можливість паралельного спілкування з клієнтами;

- персоналізація обслуговування, цілодобова робота, збільшення швидкості реакції на запити клієнта;

- можливість використання гнучких цінових моделей, висока швидкість зміни ринкової кон'юнктури;

- чіткий таргетинг і контроль рекламних і PR-інструменти для просування товарів і послуг підприємств;

- поява нових технологій продажів і обслуговування клієнтів;

- інтерактивна участь споживача у визначенні конкурентоспроможних властивостей і дизайну кінцевого продукту;

- можливість впроваджувати в практику комерційної діяльності системи автоматизації маркетингової діяльності, такі як планування і управління ресурсами підприємства (ERP- 
системи), управління зв'язками з клієнтами (CRM-системи), системи електронного документообігу, електронні платіжні системи і т.д.;

- зниження витрат за рахунок виконання деяких функцій комерційної операції самими користувачами та окремих накладних витрат;

- зручність здійснення покупки та відстеження доставки товару для клієнта;

- широкі можливості вибору каналів просування;

- менші обсяги вкладень для виходу на ринок з боку суб'єктів електронної комерції.

Що стосується недоліків, то зазвичай продавці їх пов'язують 3 необхідністю реагування на високу швидкість зміни технологій електронного бізнесу; постійною потребою в нарощуванні потужностей телекомунікаційного обладнання свого підприємства; складністю інтеграції застосовуваних інформаційних систем 3 обладнанням для електронного бізнесу; постійно виникають проблемами в забезпеченні безпеки і надійності інформаційних систем; складністю підготовки та перепідготовки персоналу, особливо в зв'язку з глобальними проблемами ринку (мовний бар'єр, політичне середовище, мінливі валютні курси, правові проблеми та ін.).

Інфраструктура електронного ринку - це сукупність об'єктів, що обслуговують ринок, забезпечують реалізацію ринкових процесів, створюють сприятливі умови для його ефективного функціонування. Вона представлена різними типами вебсайтів, які мають різноманітне цільове призначення та роль на інтернет-ринку, а також володіють різними формами, методами, засобами, інструментами реалізації ринкових процесів. До учасників електронного ринку відносяться продавці, покупці та посередники, а також організації, що забезпечують інфраструктуру та правила ринку.

В загальному вигляді можна виділити три сектори Internetринку:

- електронний ринок роздрібної торгівлі (електронний споживчий ринок);

- електронний ринок торгівлі між підприємствами;

- електронний фінансовий ринок (банківські послуги, послуги брокерських компаній).

Основною структурною одиницею електронного ринку $є$ вебсайт. Сьогодні немає єдиної класифікації сайтів, проте аналіз 
існуючих підходів дозволив структурувати типи сайтів за критеріями їх призначення:

- бізнес-сайти: інтернет-представництва, візитки, корпоративні сайти, інтернет-вітрини, промо-сайти, інтернет-магазини, торгові площадки;

-інформаційні ресурси: тематичні сайти, інтернет-портали, блоги, каталоги сайтів;

-вебсервери: пошукові системи, почтові системи, інтернетфоруми, хостинги, дошки оголошень, соціальні мережі.

Охарактеризуємо детальніше типи сайтів та особливості їх адміністрування з точки зору придатності для того чи іншого бізнесу.

Сайт-візитка - найпростіший з усіх видів сайтів. Фактично являє собою електронну версію звичайної паперової візитки. На сайтівізитці міститься основна інформація про компанію, її контакти, види діяльності та основні послуги, що надаються. Як правило, такий сайт володіє зручною навігацією, складається з декількох сторінок і має унікальний, але простий і функціональний дизайн; ідеально підходить для компаній, які хочуть розмістити інформацію про себе і свої послуги в Інтернеті. Представлена інформація - статична, тобто на сайті-візитка не передбачається активної взаємодії користувача 3 сайтом.

Розробляється сайт-візитка для підприємств, організацій і приватних осіб. Розкрутка сайту, як правило, відбувається шляхом обміну посиланнями з тематичними ресурсами. Перевагами сайтувізитки є: низька вартість створення; швидкий запуск; можлива модернізація до більш просунутих видів вебсайтів. Проте використання такого типу сайту для просування бізнесу обмежене через малий обсяг інформації та скромний дизайн.

Представницький сайт, сайт-портфоліо - це сайт-візитка 3 розширеною функціональністю: тут можна знайти докладний опис послуг, портфоліо, відгуки, форму зворотного зв'язку та інші сервісні функції.

Сайт-каталог (вітрина) - різновид сайту-візитки, у якому вбудований каталог товарів або послуг. У каталозі міститься докладна інформація, картинки, характеристики, ціни або функція завантаження прайс-листа. Це структурований каталог продукції компанії, але організований таким чином, щоб клієнт зробив якомога менше кліків, для того, щоб знайти потрібний товар. Купівля товарів 3 каталогу проводиться через e-mail, телефон або інші способи зв'язку з власником ресурсу. Варто зауважити, що на даний момент часу сайт-каталог - це не найкраще рішення для бізнесу (винятком $€$ 206 
каталоги з дорогими товарами, такими як спецтехніка, автомобілі і т.д.), оскільки не дозволяє автоматизувати процес купівлі.

Корпоративний сайт - це повноцінне представництво компанії в Інтернеті. Це багатофункціональний сайт, який містить повну інформацію про фірму, послуги чи продукцію, які вона пропонує, тощо. Корпоративний сайт може включати в себе елементи інтернетмагазину, сайту-візитки і інформаційного ресурсу. Такий сайт має досить складну систему навігації та служить для роботи 3 персоналом всередині компанії, 3 постійними і потенційними клієнтами, включає повний спектр інструментів для пошуку інформації про компанію та її діяльність (пошук і фільтри, календарі подій, фотогалереї, корпоративні блоги, форуми), може бути інтегрований 3 внутрішніми інформаційними системами компаніївласника (KIC, CRM, бухгалтерськими системами). Містить закриті розділи для різних груп співробітників (корпоративні форуми, особисті кабінети, панелі адміністраторів з різними правами доступу до інформації) і т. д.

Оновлюється досить регулярно, його головне завдання інформування всіх стейкхолдерів компанії. Корпоративний сайт оптимальне рішення для всіх компаній, які хочуть стати лідерами у своїй сфері бізнесу. Основним завданням корпоративного представництва в мережі $\epsilon$ просування бізнесу компанії і автоматизація їі діяльності. За допомогою корпоративного сайту можна значно підвищити впізнаваність бренду.

Лендінг («посадкова сторінка») являє собою спеціально спроектовану сторінку сайту, яка покликана спонукати відвідувачів до вчинення певної дії: придбання товару, оформлення підписки, замовлення послуги тощо. Це односторінковий сайт з формою заявки, який розробляється під окрему кампанію просування продукту або послуги і $є$ сьогодні одним з ефективних інструментів продажу. Найчастіше це сайт, присвячений одному товару, категорії товарів або комплексу послуг. Використовується компаніями 3 великим асортиментом, які хочуть відокремити корпоративну інформацію від споживчої.

На такій сторінці розміщується тільки ключова інформація, яка здатна зацікавити і спонукати зробити покупку товару або замовити послуги: акції з обмеженням за часом, високоякісні фотографії, заклик до дії - ось головні пункти, з яких складається посадкова сторінка. Ефективною практикою $є$ поєднання використання інтернет-магазину та лендінгових сторінок для окремих груп товарів або тимчасових акцій. 
Промо-сайт. Починаючи випуск нової продукції або запускаючи нову товарну пропозицію, компанії роблять все можливе для отримання лояльності і визнання споживачів, а також для розширення кола постійних покупців або замовників. Зрозуміло, будь-яка новинка потребує реклами. Власне, для просування нових пропозицій і створюють промо-сайти. Крім того, промо-сайти використовуються як додаткові для проведення конкурсів, акцій, розіграшів призів або презентації чогось нового.

Завжди робиться з індивідуальним неповторним дизайном, який повинен привернути увагу клієнта. Обсяг сайту від 3 до максимум 10 сторінок (про компанії, послуги, товари, контакти). Промо-сайт - це насамперед рекламний інструмент, основним завданням якого $€$ надання користувачам найсвіжішої та актуальної інформації про товари або послуги.

Інтернет-магазин - це сайт-вітрина 3 можливістю оплати покупок онлайн, який сьогодні необхідний для збільшення продажів будь-якої компанії і призначений для розширення цільової аудиторії в інших регіонах. На цьому сайті обов'язково присутній електронний каталог продукції, $\epsilon$ функція "корзина", зворотний зв'язок, електронна платіжна система та ін. Весь сайт повинен бути розроблений таким чином, щоб зацікавити користувача і схилити його до здійснення покупки, оскільки всі відвідувачі інтернетмагазину є його потенційними клієнтами.

Переваги: зручна можливість покупки; широке охоплення аудиторії; необмежена кількість товарів на вітрині; цілодобова доступність; можливість порівняння і оцінки товарів; відносно низькі ціни за рахунок зниження витрат в порівнянні з оффлайн-магазином.

Блог - це публічний он-лайн щоденник, в якому автор викладає регулярно статті або відео записи (влог). Може бути на одну вузьку тематику або мати різні розділи. Зазвичай відвідувачі мають можливість коментування для обговорення кожного запису (поста). Може існувати окремо або бути частиною інших типів сайтів (візитка, портфоліо, каталог або Інтернет-магазин). Якісні регулярні оновлення - ось запорука успіху блогу. Використання блогів поряд 3 основними видами сайтів збільшує довіру клієнтів до продавця, формує імідж компанії як експерта в галузі.

Пошукові системи - це спеціалізовані сайти, які призначені для пошуку текстової та графічної інформації у всесвітній павутині і надають користувачам за їх запитами гіперпосилання на сторінки, сайтів, які релевантні заданому людиною пошуковому запиту. Велика частина пошукових систем сьогодні перетворилися на 
повноцінні інтернет-портали з величезним набором призначених для користувача сервісів і модулів.

Сайт-спільнота - сайт, на базі якого реалізовано співтовариство для спілкування споживачів і представників компанії (може бути самостійним сайтом або розділом сайту). Функції соціальних мереж полягають в можливості зареєстрованих користувачів знаходити в мережі певне коло людей і підтримувати 3 ними зв'язок, організовуватися в спільноти за інтересами, розміщувати власний текстовий і медіа контент, запускати рекламу.

Соціальні мережі в останні роки набувають все більшої популярності як інструмент просування бізнесу, оскільки дозволяють взаємодіяти безпосередньо 3 цільовою аудиторією, вивчати ії інтереси та потреби.

Форум - віртуальний майданчик для спілкування 3 клієнтами. Форум може бути як окремим сайтом, так і частиною основного. Найчастіше форуми створюються під певні тематики). Створення форуму виправдано в разі, коли ви маєте багато клієнтів, у яких часто виникають питання. Якщо ця умова не виконується, то виходить мертвий форум, який своєю порожнечею тільки відлякує інших потенційних клієнтів.

Портал - створюється в стратегічних цілях для збільшення інформованості всередині компанії (для персоналу), націлений на партнерів (інвесторів, державних і соціальних структур, постачальників, виробників і ін.), лояльних і постійних клієнтів. Це найбільш потужний і найскладніший вид мережевого ресурсу, який може бути присвячений як одній темі, так і декільком. Портал поєднує в собі відразу кілька видів сайтів і основною його метою $є$ надання користувачам найрізноманітнішої і актуальної інформації.

Структура сайту-порталу завжди складна. Як правило, сайти даного виду містять багато різних розділів і підрозділів, меню 3 багаторівневою вкладеністю, включає в себе велику кількість різного роду опцій і модулів. Портали - це дуже насичені функціонально та інформаційно сайти, на яких можна знайти все необхідне: новини, авторські блоги, голосування, форуми, пошукові та поштові сервіси і багато іншого. Обсяг сайту-порталу може становити сотні і тисячі сторінок.

Електронні торгові площадки, каталоги. Торговельні співтовариства, які об'єднують покупців і продавців певної галузі утворюють електронні ринки завдяки IКT шляхом електронних каталогів, торгових площадок, електронних аукціонів, електронних бірж. Такі ресурси об'єднують в єдиному інформаційному просторі 
постачальників і споживачів різних товарів/послуг, надаючи учасникам торгових угод можливість користування сервісами, які підвищують ефективність процесів.

Покупці можуть використовувати потужні інформаційнопошукові можливості електронних каталогів, порівнюючи товари за декількома характеристиками, включаючи ціну, дату постачання, гарантії, інформацію щодо обслуговування. Доходи цієї категорії торговельних майданчиків складаються традиційно з комісій за транзакції та коштів, отриманих від реклами.

Інтернет-аукціон (електронний аукціон) - різновид ЕTM, на якому кінцева ціна встановлюється упродовж відкритих торгів. Аукціон - це спосіб продажу товарів, що базується на ціновій конкуренції між покупцями. Аукціони є процедурою встановлення рівноважних цін на товар, проте ціну встановлює покупець, а продавець - правила, за якими має проводитися аукціон. Електронні аукціони проводяться упродовж досить тривалого часу (декілька днів), тому покупцям зовсім не обов'язково бути фізично присутніми за комп'ютером під час проведення аукціону. Брати участь у торгах можуть тільки зареєстровані користувачі які для цього заповнюють реєстраційну форму. Для реєстрації необхідно мати електронний банківський рахунок і отримати пароль. 3 метою продажу товару необхідно заповнити спеціальну форму і розмістити на вебсервері товар.

Електронна біржа - різновид ЕТМ, на якому ціна встановлюється під впливом попиту і пропозиції. Електронні біржі можна розділити на дві великі групи: вертикальні і горизонтальні. Вертикальні біржі функціонують у певних галузях: автомобілебудування, сільському господарстві, електроенергетиці, нафтохімії, металургії. Горизонтальні біржі спеціалізуються на окремих функціях або потребах, характерних для різних галузей, наприклад на торгівлі телекомунікаційним устаткуванням, торгівлі офісним обладнанням.

Сайт-сервіс, як правило, сконцентрований на вирішенні якоїсь однієї або декількох однотипних потреб клієнта. Сюди відносять онлайн-консультантів, хмарні хостинги, відеохостінги різні сервіси для онлайн-конвертації файлів і т.д. Для того, щоб створити успішний сервіс - необхідно вивчити потреби цільової аудиторії, вирішити їх проблеми, зробити комфортним та зручним реалізацію операцій.

Очевидно, що така велика різноманітність структур, які забезпечують реалізацію бізнес-процесів на електронному ринку надає для підприємств широкі можливості у виборі форми 
просування своєї продукції і послуг, комунікацій зі споживачами, партнерами, державними органами

Висновок. Таким чином, вихід на електронний ринок перспектива для розширення та диверсифікації діяльності в будьякій сфері. Проте особливості бізнес-діяльності в різних галузях, специфіка продукту, масштаби зумовлюють необхідність оцінити придатність того чи іншого елементу інфраструктури електронного ринку, вибору релевантних форм і методів управління і просування.

1. Плескач В. Л., Затонацька Т. Г. Електронна комерція : підручник. Київ : Знання. 2007. 535 c. 2. Романенко О.M. Інтернет маркетинг. URL: https://stud.com.ua/64250/marketing/internet-marketing (дата звернення: 12.03.2021). 3. Шалева О.І. Електронна комерція. URL: https://pidru4niki.com/14100821/informatika/elektronna_komertsiya (дата звернення: 12.03.2021).

\section{REFERENCES:}

1. Pleskach V. L., Zatonatska T. H. Elektronna komertsiia : pidruchnyk. Kyiv : Znannia. 2007. 535 s. 2. Romanenko 0. M. Internet marketynh. URL: https://stud.com.ua/64250/marketing/internet-marketing (data zvernennia: 12.03.2021). 3. Shaleva 0. I. Elektronna komertsiia. URL: https://pidru4niki.com/14100821/informatika/elektronna_komertsiya (data zvernennia: 12.03.2021).

Frolenkova N. A. [1; ORCID iD 0000-0003-4553-9547], Candidate of Economics, Associate Professor

${ }^{1}$ National University of Water and Environmental Engineering, Rivne

\section{INFRASTRUCTURE MANAGEMENT OF THE ELECTRONIC MARKET}

The statistic values are the main changes in the activity of the current business structures on the electronic market. The electronic market is a system of economic information in the virtual space, which is stored between the sub-units of economic activity, the maintenance of electronic business, the storage of goods, the implementation of goods, and the post and The electronic market is a middle-class with more thorough competition, not a traditional market. There is a large number of sellers and buyers on the electronic market, there are practically no barriers to enter the market for new participants, and there is free access to information. The infrastructure of the electronic market, which is represented by different types of websites, is the price of the purchase of the market, the maintenance of the market, the prevention of the implementation of the 
market processes, the creation of friendly minds for its effective function. The elements of infrastructure can be used for the role on the Internet market, as well as in different forms, methods, methods, and tools for realizing market processes. Prior to the participants in the electronic market, sellers, buyers and middlemen, as well as organizing, to ensure that the infrastructure and rules of the market are taken care of. Characterized types of websites, such as elements of the market infrastructure: site visits, catalog, landing pages, portfolio, corporate, online store, portals, trading platforms, internet services, privacy and the significance of these passages and shortcomings from the point of view of property for the management of business in the presence of the particularities of performance and the sphere of implementation.

Keywords: electronic market; infrastructure; market participants; website.

Фроленкова Н. А. ${ }^{[1 ;}$ ORCID iD 0000-0003-4553-9547], к.э.н., доцент

${ }^{1}$ Национальный университет водного хозяйства и природопользования, г. Ровно

\section{УПРАВЛЕНИЕ ИНФРАСТРУКТУРОЙ ЭЛЕКТРОННОГО РЫНКА}

В статье определены основные предпосылки деятельности современных бизнес-структур на электронном рынке. Определены основные участники и особенности функционирования элементов инфраструктуры электронного рынка. Охарактеризованы различные типы веб-сайтов как элементы рыночной инфраструктуры.

Ключевые слова: электронный рынок; инфраструктура; участники рынка; веб-сайт.

Отримано: 14 березня 2021 p. Прорецензовано: 19 березня 2021 р. Прийнято до друку: 26 березня 2021 р. 